\title{
Quantitative Anatomical Studies on the Postnatal Development of the Cerebellum of the Albino Rat*
}

\section{H. Heinsen}

Abteilung Anatomie der RWTH Aachen, Melatener Str. 211, D-5100 Aachen, Federal Republic of Germany

\begin{abstract}
Summary. The quantitative postnatal changes of the cerebella of 65 Wistar rats aged 2-120 days have been examined. The cerebellar volume increases in two phases: The first phase lasts from birth to the seventh postnatal week. The second phase begins ten weeks post partum and lasts for a longer period than the first phase.

The cerebellar surface increases continuously from birth to the end of the seventh week.

The volume of the external granular layer is maximal when the organ grows rapidly. The external granular layer has nearly disappeared 24 days after birth; the volume of the internal granular layer is maximal at this time. Later on, the volume and the width of the internal granular layer decrease. Myelinization of the cerebellar fibers and growth of the molecular layer run parallel to this decrease. The second late, but protracted growth of the cerebellum, ten weeks after birth, is due to an increase of the molecular and medullary layer. These findings are in good accord with histological, histochemical, and ultrastructural observations of other authors.
\end{abstract}

Key words: Cerebellum - Albino rat - Ontogeny - Quantitative anatomy.

\section{Introduction}

During recent years the histo- and cytogenesis of the cerebellum of the white mouse and rat has been studied extensively (Uzman, 1960; Miale and Sidman, 1961; Altman, 1966, 1969, 1972a, b, c, 1975, 1977; Altman and Das, 1966; Das, 1976; Fujita, 1967). As demonstrated for all parts of the cerebellum and its layers, there is no synchronous development. Larsell (1952) already differentiated phylogenetically younger and older parts in the cerebellum. In contrast to the extensive investigations on cerebellar morpho- and histogenesis only few quantitative data are available on the postnatal cerebellar growth. Raaf and Kernohan (1944) examined the development of the cerebellum in human beings, Haddara and Nooreddin (1966) in the albino mouse, and Oster-Granite and Herndorn (1976) in the Syrian Hamster. The development of the cerebellum is a complex process, on the one hand composed of

* Supported by the Deutsche Forschungsgemeinschaft LA 184/3. 
changes of the fine structure of the cortical layers in general, and on the other hand not confined to alterations in single neurons. The attempt of the present study is the analysis of the quantitative postnatal cerebellar growth on the basis of the quantitative changes in the cortical and medullary layers with regard to the well-known histological and ultrastructural differentiations. It is shown that the cerebellar maturation and growth are extremely protracted, outlasting the well-studied differentiation in the fine structures at least in the order of months.

\section{Materials and Methods}

The cerebella of 65 female Wistar-rats, aged 2-120 days, were examined. The animals were deeply anesthetized with Nembutal ${ }^{\odot}$ and perfused by Bouin's fluid injected into the left ventricle. After decapitation, the crania were exposed to Bouin's solution for two days. Bouin's solution is slightly decalcifying. So it was easier to remove the cerebella with their paraflocculi. The specimens were, according to Romeis (1948), embedded into paraffin wax, and serial sections were cut at $8 \mu \mathrm{m}$. The sections were stained according to the method of Einarson (1932), and every tenth section was used for measurements by the "Integrationsokular" of Zeiss (Henning, 1958). The volumes of the cerebellar nuclei could not be determined separately, because it was impossible to outline exactly the nuclei from the surrounding medullary layer.

The volumes obtained were multiplied, according to Stephan (1959), Leibnitz (1967), and Wingert (1969), by the factor 1.85 in order to calculate the assumed volumes of the unfixed organ. The cerebellar surface was determined by the method of Henning (1956). The shrinkage of the surface after fixation and embedding was corrected by the factor 1.47 (Stephan, 1959). In order to determine the width of the cortex, it is appropriate to use the formula by which the cortical volume is divided by the cerebellar surface. Taking into account the percentual distribution of the single layers and of the total cortical layer, one can easily calculate the average width of the molecular layer and the external and internal granular layers.

\section{Results}

\section{The Growth of the Cerebellar Volume}

The volume of the cerebellum increases during the second to ninth postnatal day from $15 \mathrm{~mm}^{3}$ to $45 \mathrm{~mm}^{3}$, the initial volume being trebled within one week (Fig. 1, Fig. $8 \mathrm{a}$ and $\mathrm{b}$ ). This increase is small compared to the growth of the cerebellum between the 9 th and 17 th day of life, during which the volume increases rapidly up to $180 \mathrm{~mm}^{3}$ (Fig. 8c and d). As shown in Figure 1, this postnatal growth period is represented by an almost vertically running curve. After the 17 th day of life, the growth of the cerebellum appears to take place more slowly. The curve approaches asymptotically to an average volume of $225 \mathrm{~mm}^{3}$. The cerebellar volume seems to remain constant at this level until the end of the tenth postnatal week. After this, a further slight but protracted increasing growth can be recorded. The end of this longlasting process has not been determined in this study. At the end of the 120th postnatal day, the cerebellar volume reaches about $255 \mathrm{~mm}^{3}$ (Fig. 8e, f). This volume, actually, is 17 times that of the initial volume during the second day of life.

\section{The Growth of the Cerebellar Surface}

The increase of the total cerebellar volume is accompanied by an enlargement of the cerebellar surface. At the age of two days, the cerebellar surface expands to $43 \mathrm{~mm}^{2}$ (Fig. 2). During the following four days, this value is doubled. At the sixth postnatal 


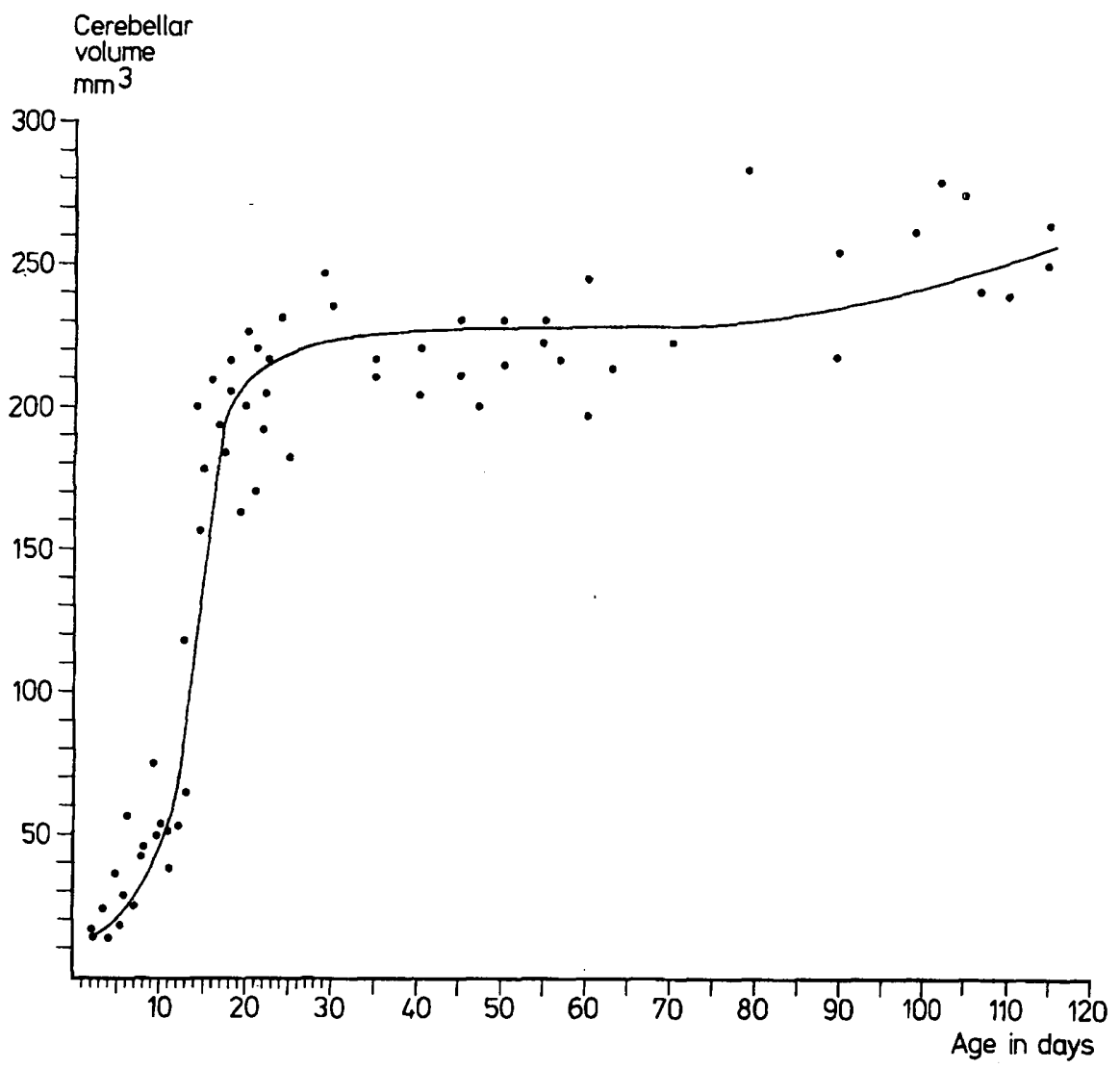

Fig. 1. The growth of the total cerebellar volume in relation to age

day the average cerebellar surface amounts to $90 \mathrm{~mm}^{2}$ (Fig. $8 \mathrm{a}, \mathrm{b}$ ). Between the 6 th and 15th postnatal day, surface development shows a rapid increase. In this period, the average cerebellar surface amounts to about $440 \mathrm{~mm}^{2}$ (Fig. 8c, d). This increase of the surface is due mainly to the onset of foliation in the cerebellar cortex. From the 15th to the 50th day of life, the growth of the cerebellar surface is small. The cerebellar surface measures about $530 \mathrm{~mm}^{2}$ in animals older than 50 days. After the 70th day of life, there is no indication of new surface growth.

\section{The Growth of the Cerebellar Cortical Layers}

The growth of the cerebellar cortex is due to the increase in the volume of its layers. It is a complex process resulting in the disappearance of the external granular layer, and lasts for a very long period. It appears appropriate to examine firstly the external granular layer because this serves as a matrix zone for the internal granular layer and the molecular layer; subsequently it disappears in a relatively short time.

3.1. The Changes in the External Granular Layer. The volume of the external granular layer is, even when maximal expansion is reached, not at all as obvious as 


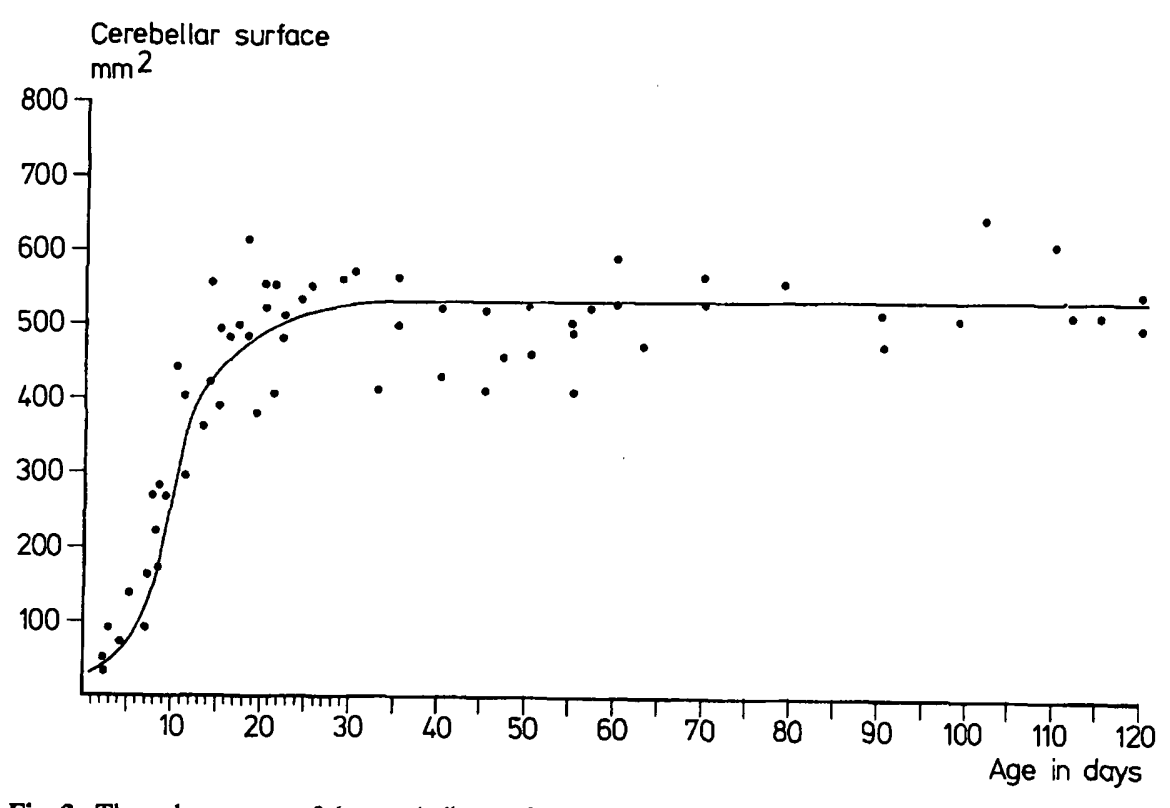

Fig. 2. The enlargement of the cerebellar surface in relation to age

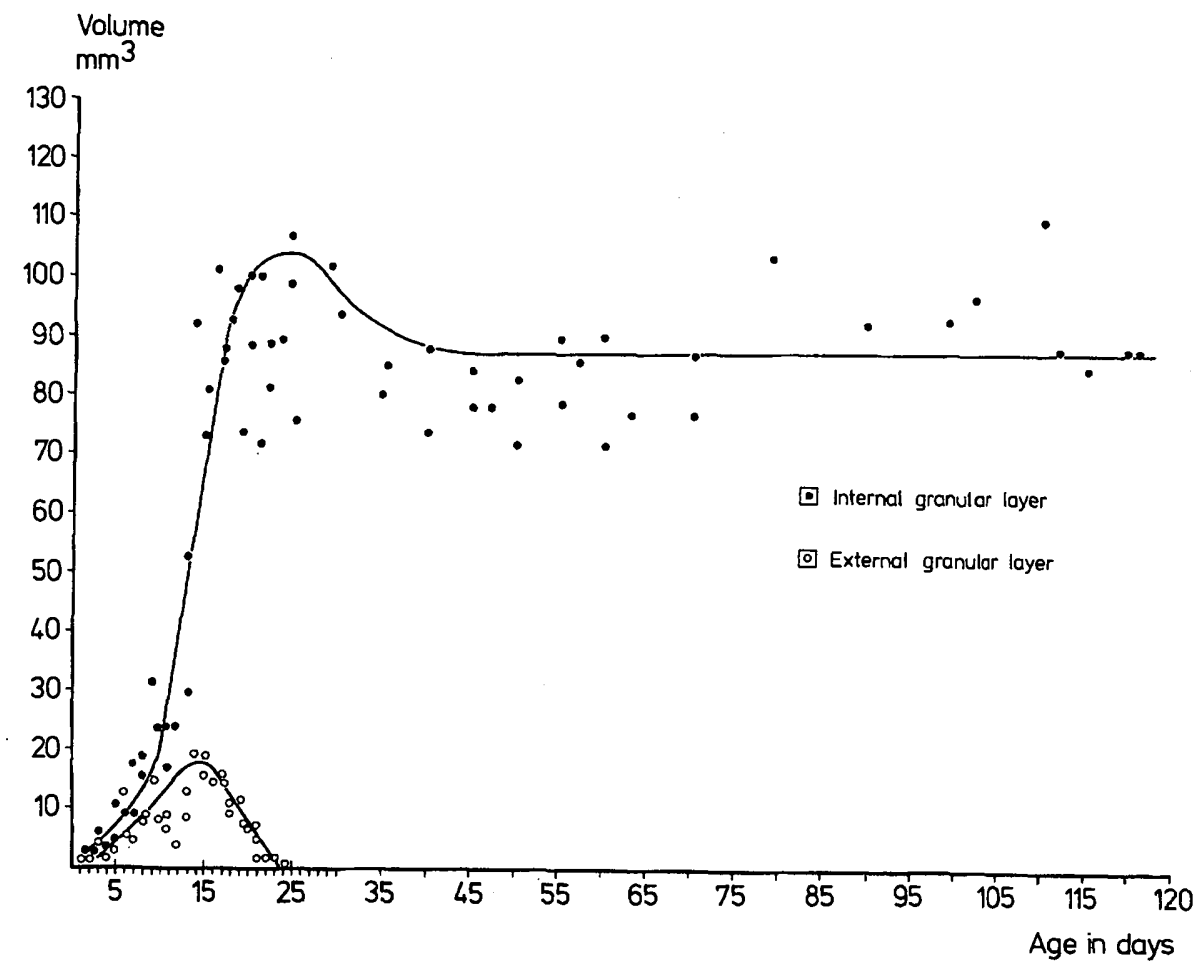

Fig. 3. The volumes of the external and internal granular layer and their changes with time 
the volumes of the definite internal granular layer or the molecular layer (Fig. 3). For example, at the 24th postnatal day the volume of the internal granular layer is five times larger than the volume of the external granular layer at the 14th day. From the second to sixth day of life, the volume of the external granular layer is trebled from 2 to $6 \mathrm{~mm}^{3}$. Up to the ninth day, the growth of the external granular layer is in accord with the proliferation of the molecular and the internal granular layer; the curves run parallel (Figs. 3, 4). With the onset of a marked growth of the cerebellar surface and volume and the enlargement of the molecular layer (Fig. 4), the growth of the external granular layer slows down. About the 14th day of life, the external granular layer reaches the maximum of its development with $18 \mathrm{~mm}^{3}$ (Fig. 8c, d). This volume is nine times greater than the initial volume (Fig. 3).

During the following ten days, the volume of the external granular layer decreases rapidly. Twenty-four days after birth, the layer disappears with the exception of some small residues (Chan-Palay, 1972). The external granular layer consists, depending on the age of the animals, maximally of eight to ten rows of cells which are not sharply delineated from the molecular layer. Therefore, the exact measurement of the external granular layer is sometimes difficult. Beyond this, individual variations in this rapidly changing layer make it impossible to draw an exact curve (Fig. 5). Nevertheless, two characteristic regions in the diagram can be described. From the second to the sixth day, the width of the outer granular layer enlarges from 35 to $75 \mu \mathrm{m}$ (Figs. 5, 8a, b) with a peak at the end of the first postnatal week. From the 6 th to the 13 th day, the width of the external granular layer decreases to about $30 \mu \mathrm{m}$ and remains nearly unchanged until the 17th day (Fig. 8c,

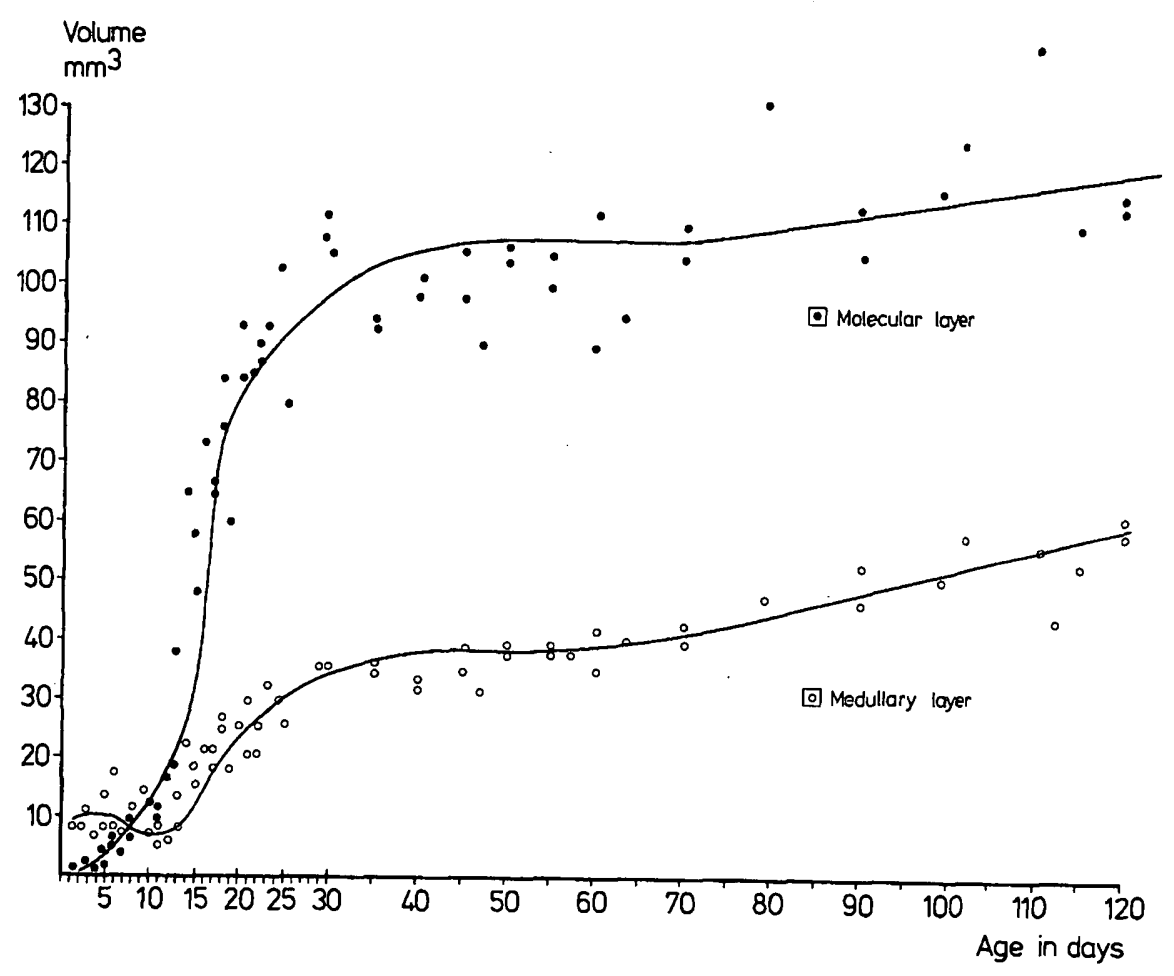

Fig. 4. The volumes of the molecular and medullary layer and their changes with time 


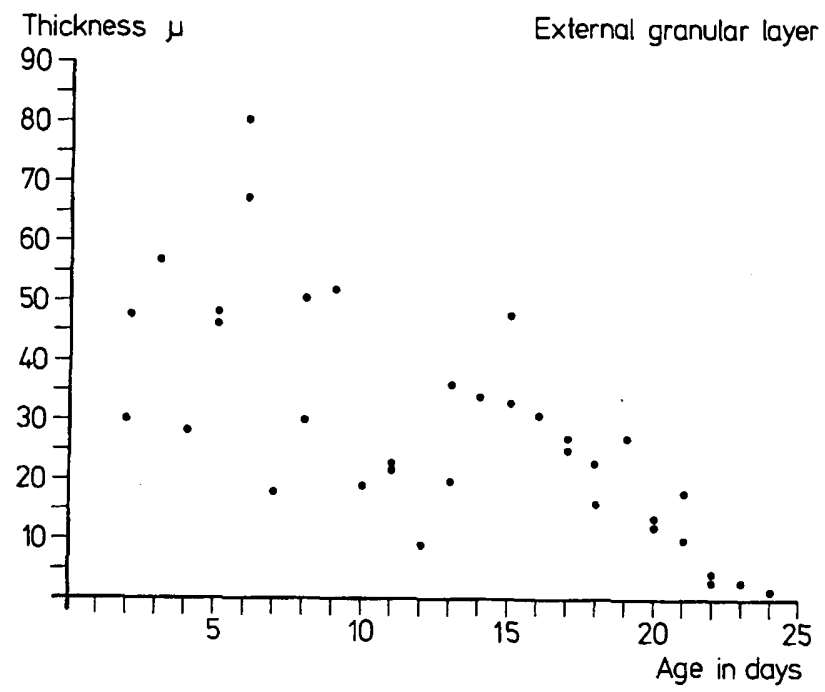

Fig. 5. The thickness of the external granular layer in rats 2-24 days old

d). From the 17th to the 24th day, the diameter of the external granular layer decreases continuously and the layer finally disappears.

3.2. The Postnatal Growth of the Molecular Layer. Because of the existence of the external granular layer, the molecular layer is the smallest one of the three

Thickness $\mu$

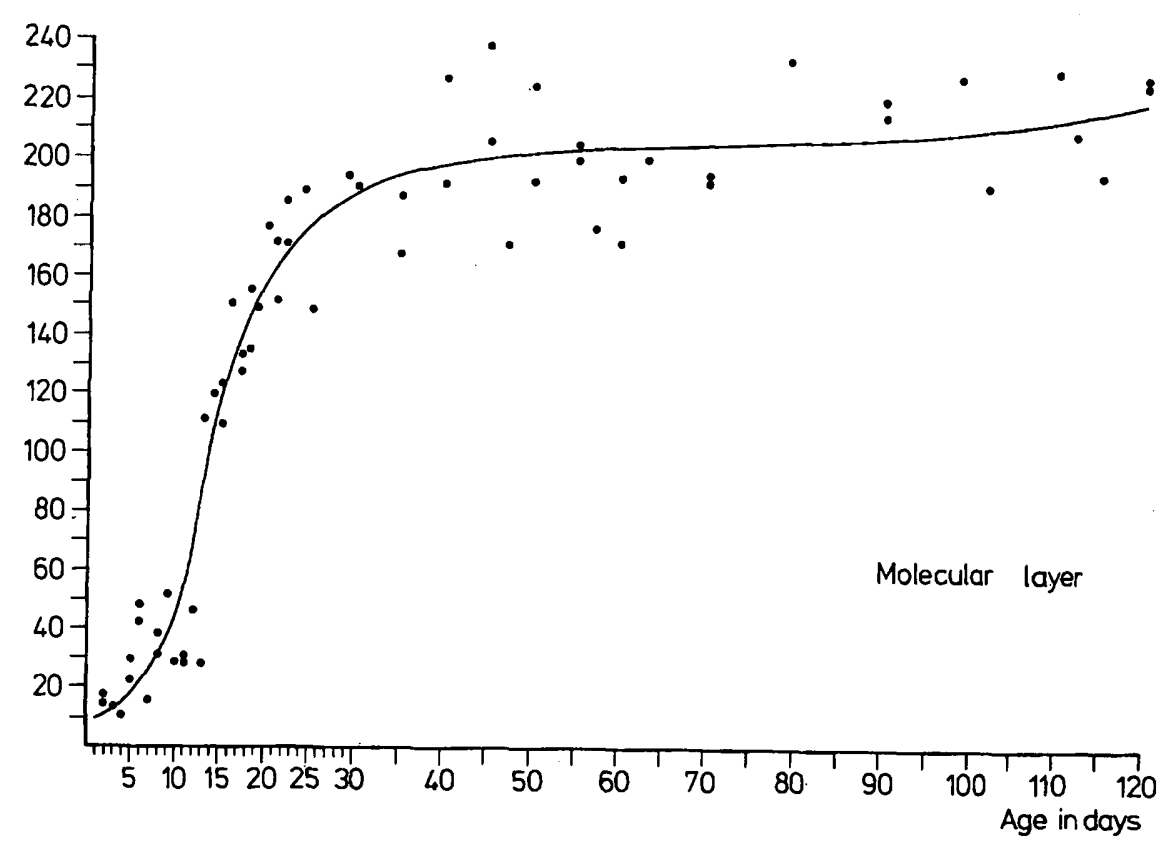

Fig. 6. The thickness of the molecular layer and its changes in rats from the 2 nd-120th day of life 
cortical layers in early developmental stages (Fig. 4). From the second to the ninth day, the average volume is augmented from $1 \mathrm{~mm}^{3}$ to $10 \mathrm{~mm}^{3}$. There is a phase of maximal growth about the 9th to 25th day. At the end of this period, the volume amounts to $91 \mathrm{~mm}^{3}$. Subsequent growth till the 50th day post partum is significantly slower, only $15 \mathrm{~mm}^{3}$ being added. At the end of the 70th day of life, the molecular layer has an average volume of about $106 \mathrm{~mm}^{3}$.

Seventy days post partum, a new faint growth begins. It lasts until the 120th day or even longer. The average volume of the molecular layer reaches $120 \mathrm{~mm}^{3}$.

At the second day of life, the molecular layer is hardly recognizable. It has an average width of only $10 \mu \mathrm{m}$ (Fig. 6). Within one week, the layer enlarges to $35 \mu \mathrm{m}$. The phase of a marked growth lasts for two weeks from the 9th to the 25th day of

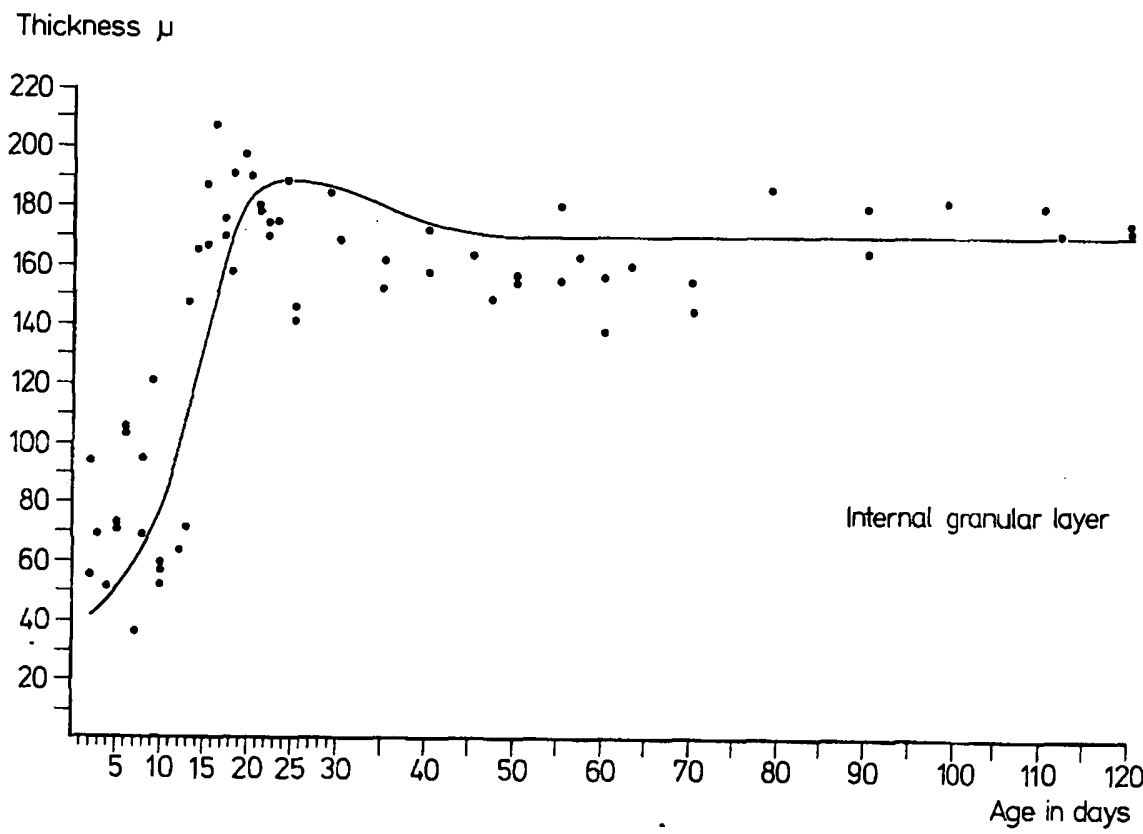

Fig. 7. The thickness of the internal granular layer in 2-120-day-old rats

life. The depth of the layer augments from $35 \mu \mathrm{m}$ to $175 \mu \mathrm{m}$. This is followed by a period of moderate growth. At the end of the seventh week, the depth of the molecular layer is about $200 \mu \mathrm{m}$. Simultaneously with the enlargement of the volume, the width of the layer enlarges from 200 to $220 \mu \mathrm{m}$ between the beginning of the 7th week and the 120th day of life.

3.3. The Quantitative Postnatal Changes of the Internal Granular Layer. During the first two weeks after birth the growth of the internal granular layer is comparable to the growth of the molecular layer (Figs. 3 and 4). The volume increases during the first week from 3 to $9 \mathrm{~mm}^{3}$ (Fig. 3), between the 6th and 18th day post partum from 9 to $92 \mathrm{~mm}^{3}$. About 24 days after birth, the internal granular layer has attained its maximal extension. In the following days the maximal volume is reduced by $20 \%$. The average volume of the internal granular layer in the oldest animals amounts to $87 \mathrm{~mm}^{3}$. From the second to the sixth postnatal day, the width of the internal 

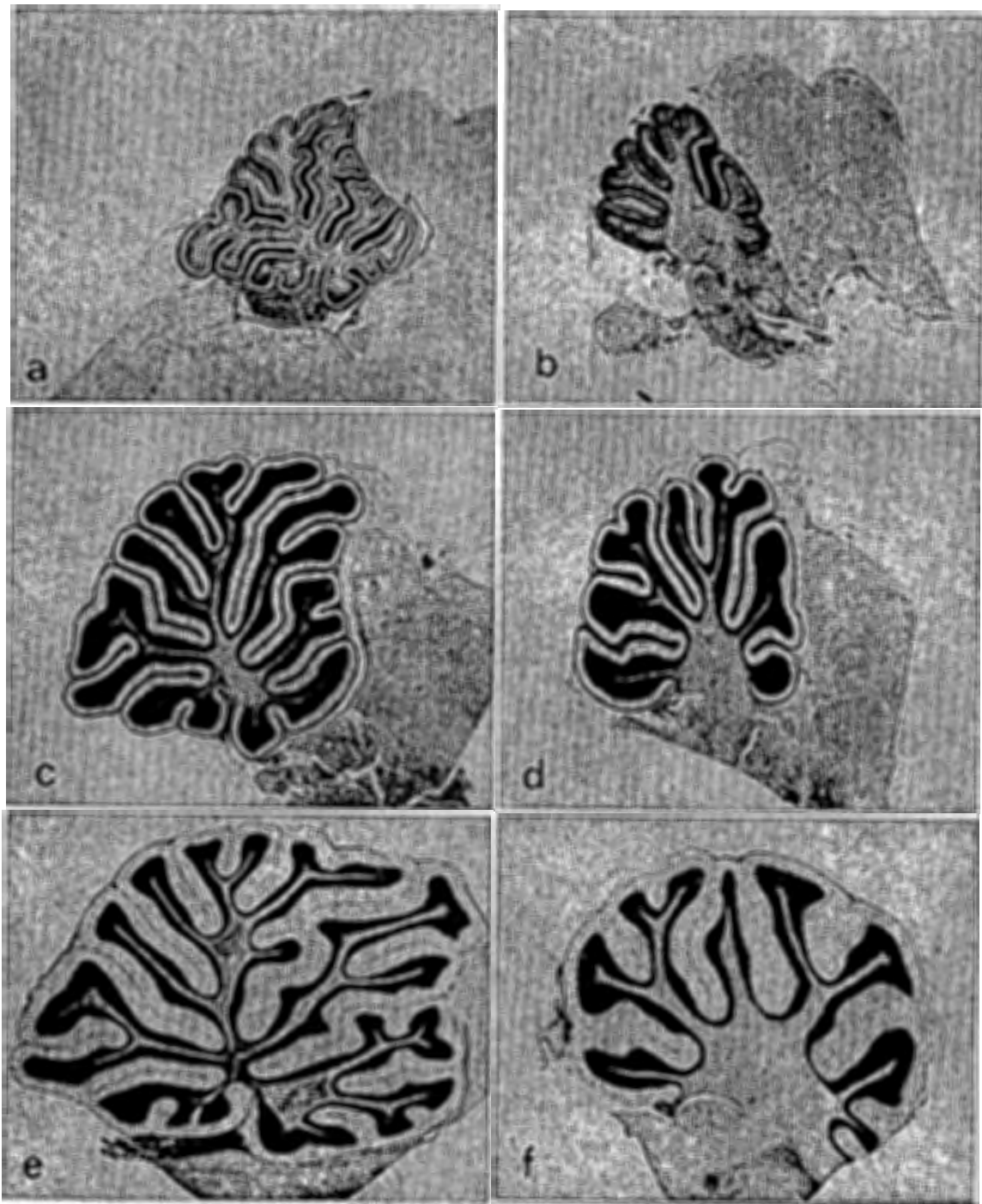

Fig. 8a-f. Mediosagittal sections (left column) through the cerebellar vermis of rats aged 6 days (a), 15 days $(\mathbf{c})$ and 120 days (e).

Parasagittal sections through the cerebellar hemisphere (right column) of rats aged 6 days (b), 15 days (d) and 120 days (f). All sections of the right column are equidistant to the mediosagittal plane in relation to the growth of the whole cerebellum.

Note the thickness of the external granular layer in 6- and 15-day-old specimens (Fig. a-d) and the enlargement of the medullary layer (Fig. $f$ ) $\times 9$

granular layer remains nearly constant (Fig. 8a, b). Between the 6th and the 18th day post partum the depth enlarges from 55 to $175 \mu \mathrm{m}$ (Fig. 8c, d). Twenty-four days post partum, the depth of the internal granular layer is maximal with $185 \mu \mathrm{m}$. Thereafter the diameter of this layer is reduced until the end of the seventh week; it seems to remain constant at $170 \mu \mathrm{m}$ (Fig. 7). 
3.4. The Postnatal Growth of the Cerebellar Medulla. It is nearly impossible to delineate the region of the definite white matter of the cerebellum and the immature cellular elements in the developing internal granular layer. This is the reason why the data vary to a great extent during the first days of life (Fig. 4); this variance seems to become less between the 6th and the 12th to $6 \mathrm{~mm}^{3}$ (Fig. 8a, b). Only after the second week post partum is it possible to delineate the medullary and the internal granular layer in all parts of the rat's cerebellum. After this, the volume begins to grow. This growth is not as rapid as the growth of the cerebellar cortex. At the end of the 40 th postnatal day, the medulla has a volume of $38 \mathrm{~mm}^{3}$ (Fig. 4). Between the seventh and the tenth week the volume of the medulla is practically unchanged. Ten weeks after birth there is again an increase in volume. The volume of the medullary layer increases a further $16 \mathrm{~mm}^{3}$ up to an average value of $56 \mathrm{~mm}^{3}$. in animals aged 120 days (Fig. 8e, f).

\section{Discussion}

Postnatal quantitative growth of the brain or parts of it has been investigated in man and in various species by a number of authors (e.g. Dubois, 1897; Snell, 1891; Spann and Dustmann, 1965; Wingert, 1969; Emele, 1970). Measurements in the rat have been published by Donaldson and Hatai (1931), but these authors did not measure the postnatal changes in the individual cerebellar layers. As far as possible, our own results will be related to their data.

During the first three weeks of life, the data of Donaldson and Hatai (1931) accord with my own data (Fig. 1). But from four to seven weeks after birth the cerebella of the animals used in this study are $10-15 \mathrm{mg}$ heavier than theirs. However, the slopes of both curves are similar during this time. One can recognize a new onset of growth of the volume between the 70th and 120th day of life. This growth seems to be extremely prolonged. Rats $240,360,378$ days and $2 \frac{1}{2}$ years old have a cerebellar weight of more than $300 \mathrm{mg}$. Details will be presented in a following paper. Emele (1970) and Wingert (1969) did not observe a similar late second growth in the cerebella of albino mice, whereas Kretschmann and Wingert (1971) do not exclude this phenomenon.

Comparison of the cerebellar volume (Fig. 1) with that of its surface (Fig. 2) yields some differences. The rapid growth of the cerebellar surface starts earlier than the growth of its volume. This fact can be explained as follows: The surface enlarges by an early folding of the cortex. The formation of the cerebellar fissures has, according to Addison (1911) and Lauder et al. (1974), terminated at the 10th day post partum. Four weeks post partum, the growth curve of the surface attains an asymptotic level at about $530 \mathrm{~mm}^{2}$. There is no substantial growth to be seen ten weeks post partum; but the volume increases between the 70th and 120th day from $233.35 \pm 12.94$ to $262.94 \pm 2.88 \mathrm{~mm}^{3}$. These late quantitative changes, which do not find their expression in a surface enlargement, must occur in the depth of the cerebellum: The thickness of myelinated fibers may be augmented, the cerebellar pedunculi may be enlarged.

No relevant data concerning the growth of the cerebellar surface of albino rats. during ontogenesis have been found in the literature. Only those published by Inukai (1928) and Lange (1970) could be considered. Both authors found that the cerebellar surfaces of adult rats vary between 440 and $544 \mathrm{~mm}^{2}$.

The data of Haddara and Nooreddin (1966), Altman (1969), and Oster-Granite and Herndorn (1976) do not directly show the growth of the cerebellar surface in the 
species examined. Haddara and Nooreddin (1966) conclude that the short-termed rapid growth of the cerebellar cortex and the long-termed growth of the cerebellar medulla is the reason for an early formation of the cerebellar fissures and lobules. According to Mares et al. (1970) and Lauder et al. (1974), the enlargement of the cerebellar surface consists of at least two components: between the 5th and the 10th day, the number of fissures is raised; in the following days, until the 24th postnatal day, the depth of the fissures increases.

The cerebellar histo- and cytogenesis from cyclostomes to man is well known (Ramon y Cajal, 1911; Jakob, 1929; Jansen and Brodal, 1958; Fox and Snider, 1967; Eccles, Ito and Szentagothai, 1967; Miale and Sidman, 1961; Fujita et al., 1966; Altman, 1966, 1969, 1972a, b, c, 1975, 1977; Altman and Das, 1966; Rakic, 1973). Publications on quantitative changes of the cerebellar layers during ontogenesis are rare, although they are important for elucidating developmental changes within the cerebellum. Comparing Figures 3 and 5 , it is striking that the width of the external granular layer is maximal at the sixth postnatal day (75 to $80 \mu \mathrm{m}$, Fig. $8 \mathrm{a}$, b). During the following days, the width of the external granular layer is reduced, but remains relatively constant at a thickness of $30 \mu \mathrm{m}$ between the 13th and the 17th day of life (Fig. 8c, d). On the other hand, the volume of the external granular layer increases and decreases continuously (Fig. 3). At the 14th day post partum, the volume reaches $18 \mathrm{~mm}^{3}$ maximally, but the width is already at its maximum at the sixth day. This retardation would appear to be contradictory; however, it can be explained as follows: Addison (1911), Ramon y Cajal (1911), and Altman (1972a) subdivide the external granular layer into two zones, an outer zone of epitheloid (Ramon y Cajal, 1911) or proliferative cells (Altman, 1972a) and an inner zone of bipolar (Ramon y Cajal, 1911) or premigratory cells. Altman (1972a) postulates an optimal depth of 4-5 rows of cells for the proliferative zone. If the rate of mitosis in the proliferative zone is greater than the rate of transformation, there results an accumulation of cells in the premigratory zone. Hence the depth of the external granular layer increases to up to ten rows of cells between the eighth and ninth day of life. The moderate growth of the cerebellum results in an accumulation of cellular elements in the outer granular layer (Altman, 1969). According to Addison (1911), the width of the external granular layer averages about $54 \mu \mathrm{m}$ eight to ten days after birth; according to Greis (1970) already at the sixth day post partum it is about 37 $\mu \mathrm{m}$. As Addison (1911) and Altman (1972a) suggest, the decrease in the width of the external granular layer must not necessarily coincide with the reduction of the total sum of the stem cell population. The enlargement of the cerebellar surface results in the distribution of the stem cells over the cerebellar surface (Altman, 1969). Indeed, the decreasing width of the external granular layer coincides exactly with the onset of a rapid enlargement of the cerebellar surface (Figs. 2, 5). The total volume of the external granular layer - neither Addison (1911) nor Altman (1969) nor Greis (1970) had measured this volume - increases up to the 14th day. Between the 13th and 17th day of life, the rate of mitosis is sufficient to ensure that, in spite of continuous surface growth, the width of the layer remains constant.

The border between the immature internal layer and the immature medullary layer is not clearcut. In this region, the cells of two (Ramon y Cajal, 1911 and Fujita et al., 1966) or three germinal centers (Altman et al., 1968) intermingle, thus complicating the demarcation of these two layers. This is the reason why the data vary to so large an extent in Figure 3 and Figure 4. During the first weeks after birth, the growth of the internal granular layer is moderate, and then rapid until the middle of the third week. Twenty-four days post partum, the depth of the internal granular layer is maximal (Fig. 3). At this time, the external granular layer has 
almost disappeared. But a few days after the 24th day, depth and volume of the internal granular layer decrease rapidly. This phenomenon was already described by Altman (1969). Haddara and Nooreddin (1966) reported a decrease in the cerebellar cortical area. Up to the seventh week post partum, the volume of the internal granular layer decreases by $17 \mathrm{~mm}^{3}$, the width of this layer by $15 \mu \mathrm{m}$. (Figs. 3, 7). The mechanisms (cell death of granule cells, increasing packing density, growth of the vascular system) are subject of a further study, the results of which will be published later. The average depth of the internal granular layer of adult rats is $170 \mu \mathrm{m}$. Addison (1911) reported $120 \mu \mathrm{m}$ for 21 day old rats. Greis (1970) $142 \mu \mathrm{m}$, whereas Lange (1970) calculated an average depth of $171 \mu \mathrm{m}$.

The growth of the molecular layer is more protracted. Growth is not clearly visible during the second and ninth postnatal day, rapid between the 9th and 25th day and less from the 25th day to the beginning of the seventh week post partum. These three periods can be easily compared with the subdivision given by Altman (1972b) on the basis of histological findings in this layer. The appearance of the apical cones of the Purkinje cells raises the depth of the molecular layer only slightly. The rapid growth of the molecular layer - according to Altman (1972b), during the second week of life - is due to the rapid growth of the dendritic system, The formation of parallel fibers and of glial processes. The interposition of glial processes is a slow process outlasting neurogenesis for ten days. Rakic (1973) on the other hand emphasizes the role of late maturing granule cell axons for the protratced growth in the depth of the molecular layer. In the pyramis, to which Altman always refers when determining morphological changes, this process of maturation of the molecular layer would seem to come to an end at the 30th day of life. My own data suggest that the growth of the molecular layer is temporarily terminated at the beginning of the seventh week post partum. The pyramis seems not to be representative of growth processes in the total cerebellum. Ten weeks after birth, Altman (1969) does not find a new onset of growth in the molecular layer. According to his Figure 2, the area of the molecular layer decreases. My own data suggest that the volume increases between the 10th week and the 120th day post partum for another $14 \mathrm{~mm}^{3}$, the depth of the layer enlarging from 200 to $220 \mu \mathrm{m}$. Up to the present, it is not known for certain which elements contribute to the increase of the molecular layer between the 70th and 120th day. Addison (1911) suggests that the Purkinje cell dendrites may branch continuously until the 110th day; however, he gives no quantitative data.

It has already been mentioned that the internal granular layer and the medullary layer in young animals are not sharply demarcated. According to Fujita et al. (1966), there are six developmental stages in the cerebellum of mice. These stages result from the migration of undifferentiated cells emerging from the ventricular matrix cell-system and the externum matrix cell-system. The concept of Fujita (1966) could explain the initial decrease of the medulla (Fig. 4). Neuroblasts migrate downwards from the external granular layer, forming the internal granular layer. Until the 12th day this is at the expense of the medulla. From the 12th day onwards, Kuckuck (1967) finds myelin sheaths in paraffin embedded sections. During the following days more and more myelinated fibers are formed. The volume of the medullary layer increases from $10 \mathrm{~mm}^{3}$ to $38 \mathrm{~mm}^{3}$. This process continues as long as does the process of growth of the molecular layer. The total increase amounts to about $18 \mathrm{~mm}^{3}$, and is a little more than the growth of the molecular layer in the same period. It is not clear whether both layers grow independently one from the other, or whether the one is necessary for the other, which neuronal, glial or vascular structures grow and what is the physiological significance of this long-lasting growth. 
Histochemical investigations in the cerebellum reveal chronological differences in the maturation of the cerebellar layers (Ortmann, 1957; Knolle, 1959; Labedsky and Lierse, 1968; Kuckuck, 1967; Iglesias et al., 1973). The external and internal granular layer are early maturing structures. This is also suggested by my own quantitative findings. Flexner, L.B. and Flexner, J.B., 1949; Flexner, J.B., Tyler, D.B., and Gallant, L.J., 1950, introduced the term "critical period" as decisive for the development and onset of function in the central nervous system. According to Robins and Lowe (1961), lipid deposition and protein storage in the molecular and medullary layers are maximal between the 9th and 14th postnatal day. My own diagrams (Figs. 1, 3, and 4) show, besides the rapid volume increase of the molecular and the internal granular layer, the completed demarcation of the medullary and the internal granular layer and the onset of growth in the medulla (Fig. 4). Snider and Jacob (1949) found an electric activity in the rat's cerebellum on the same day.

\section{References}

Addison, W.H.F.: The development of the Purkinje cells and of the cortical layers in the cerebellum of the albino rat. J. Comp. Neur. 21,487-495(1911)

Aitman, J.: Autoradiographic and histological studies of postnatal neurogenesis. II. A longitudinal investigation of the kinetics, migration and transformation of cells incorporating tritiated thymidine in infant rats, with special reference to neurogenesis in some brain regions. J. Comp. Neur. 128, $431-473$ (1966)

Altman, J.: Autoradiographic and histological studies of postnatal neurogenesis. III. Dating the time of production and onset of differentiation of cerebellar microneurons in rats. J. Comp. Neur. 136, 269-294 (1969)

Altman, J.: Postnatal development of the cerebellar cortex in the rat. I. The external germinal layer and the transitional molecular layer. J. Comp. Neur. 145, 353-398 (1972a)

Altman, J.: Postnatal development of the cerebellar cortex in the rat. II. Phases in the maturation of Purkinje cells and of the molecular layer. J. Comp. Neur. 145, 399-464 (1972b)

Altman, J.: Postnatal developmental of the cerebellar cortex in the rat. III. Maturation of the components of the granular layer. J. Comp. Neur. 145, 465-514 (1972c)

Altman, J.: Postnatal development of the cerebellar cortex in the rat. IV. Spatial organization of bipolar cells, parallel fibers and glial palisades. J. Comp. Neur. 163, 427-448 (1975)

Altman, J.: Postnatal development of the cerebellar cortex in the rat. V. Spatial organization of Purkinje cell perikarya. J. Comp. Neur. 171, 1-16 (1977)

Altman, J., Das, G.D.: Autoradiographic and histological studies of postnatal neurogenesis. I. A longitudinal investigation of the kinetics, migration and transformation of cells incorporating tritiated thymidine in neonate rats, with special reference to postnatal neurogenesis in some brain regions. J. Comp. Neur. 126, 337-390 (1966)

Das, G.D.: Differentiation of Bergmann glial cells in the cerebellum. A Golgi study. Brain Res. 11, 199-213 (1976)

Donaldson, H.H., Hatai, S.: On the weight of the parts of the brain and the percentage of water in them according to brain weight and to age in albino and in wild Norway rats. J. Comp. Neur. 53, 263307 (1931)

Dubois, E.: Uber die Abhängigkeit des Hirngewichts von der Körpergröße bei den Säugetieren. Arch. Anthropol. 25, 1-28 (1897)

Chan-Palay, V.: Arrested granule cells and their synapses with mossy fibers in the molecular layer of the cerebellar cortex. Z. Anat. Entwickl.-Gesch. 139, 11-20 (1972)

Eccles, J.C., Ito, M., Szentagothai, J.: The cerebellum as a neuronal machine. Berlin, Heidelberg, New York: Springer-Verlag 1967

Einarson, L.: A method for progressive selective staining of Nissl and nuclear substance in nerve cells. Amer. J. Path. 8, 295-307 (1932)

Emele, B.: Biometrische Untersuchungen der Frischvolumina von Rhombencephalon und Cerebellum der Albinomaus. Z. mikr. anat. Forsch. 83, 396-443 (1970)

Flexner, J.B., Flexner, L.B.: Biochemical and physiological differentiation during morphogenesis. VII. Adenylphosphatase and acid phosphatase activities in the developing cortex and liver of the fetal guinea pig. J. cell. comp. Physiol. 31, 311-320 (1948) 
Flexner, J.B., Flexner, L.B.: Biochemical and physiological differentiation during morphogenesis. IX. The extracellular and intracellular phases of the liver and cerebral cortex of the fetal guinea pig as estimated from distribution of chlorid and radiosodium. J. cell. comp. Physiol. 34, 115-127 (1949)

Flexner, L.B., Tyler, D.B., Gallant, L.J.: Biochemical and physiological differentiation during morphogenesis. X. Onset of electrical activity in developing cerebral cortex of fetal guinea pig. J. Neurophysiol. 13, 427-430 (1950)

Fox, A., Snider, R.S. (ed.): The cerebellum. Progress in brain research. London-New York: Elsevier Publ. Comp. 1967

Fujita, S.M., Shimada, M., Nakamura, T.: $\mathrm{H}^{3}$-thymidine autoradiographic studies on the cell proliferation and differentiation in the external and internal granular layers of the mouse cerebellum. J. Comp. Neur. 128, 191-208 (1966)

Greis, J.B.: The postnatal development of the cerebellar cortex in the albino rat. The Leech, Johannesburg, 40/1, 2-6 (1970)

Haddara, M.A., Nooreddin, M.A.: A quantitative study on the postnatal development of the cerebellar vermis of mouse. J. Comp. Neur. 128, 245-254 (1966)

Hennig, A.: Bestimmung der Oberfläche beliebig geformter Körper mit besonderer Anwendung auf Körperhaufen im mikroskopischen Bereich. Inhalt einer aus Papillen und Zotten gebildeten Fläche. Mikroskopie 11, 206-213 (1956)

Hennig, A.: Kritische Betrachtung zur Volumen- und Oberflächenmessung in der Mikroskopie. Zeiss Werkschrift 30, 78-85 (1958)

Iglesias, J.-R., Hernandez, F., Iglesias, R.E.: Histochemical study of ubiquinones in the central nuclei of the cerebellum during its development. Histochemie 34, 33-41 (1973)

Inukai, T.: On the loss of Purkinje cells, with advancing age, from the cerebellar cortex in the albino rat. J. Comp. Neur. 45, 1-31 (1928)

Jakob, A.: Das Kleinhirn. v. Möllendorffs Handbuch der mikroskopischen Anatomie des Menschen. 4. Nervensystem, 674-916. Berlin: Springer-Verlag 1928

Jansen, J., Brodal, A.: Das Kleinhirn. v. Möllendorffs Handbuch der mikroskopischen Anatomie des Menschen. IV/8, 1-323, Berlin: Springer-Verlag 1958

Knolle, J.: Succinodehydrogenase im Gehirn von Vögeln und Säugern. Z. f. Zellforsch. 50, 183-231 (1959)

Kretschmann, H.-J., Wingert, F.: Computeranwendung bei Wachstumsproblemen in Biologie und Medizin. Berlin, Heidelberg, New York: Springer-Verlag 1971

Kuckuck, B.: Über die Entwicklung und Chemodifferenzierung des Kleinhirns der Ratte. Histochemie 9, 217-255 (1967)

Labedsky, L., Lierse, W.: Die Entwicklung der Succinodehydrogenaseaktivität im Gehirn der Maus während der Postnatalzeit. Histochemie 12, 130-151 (1968)

Lange, W.: Vergleichend quantitative Untersuchungen am Kleinhirn des Menschen und einiger Säuger. Habil.schrift, Hamburg (1970)

Larsell, O.: The morphogenesis and adult patterns of the lobules and fissures of the cerebellum of the white rat. J. Comp. Neurol. 97, 281-356 (1952)

Lauder, J.M., Altman, J., Krebs, H.: Some mechanisms of cerebellar foliation: Effects of early hypoand hyperthyroidism. Brain Res. 76, 33-40 (1974)

Leibnitz, L.: Die Veränderungen von Gewicht, Volumen und spezifischem Gewicht des Rattengehirnes nach Fixierung, Dehydrierung und Aufhellung. J. Hirnforsch. 9, 97-104 (1967)

Mares, V., Lodin, Z.: The cellular kinetics of the developing mouse cerebellum. II. The function of the external granular layer in the process of gyrification. Brain Res. 23, 343-352 (1970)

Miale, I.L., Sidman, R.L.: An autoradiographic analysis of histogenesis in the mouse cerebellum. Exp. Neur. 4, 277-296 (1961)

Ortmann, R.: Histochemische Untersuchungen auf Succinodehydrogenase am Gehirn bei verschiedenen Vertebraten. Acta histoch. 4, 158-165 (1967)

Oster-Granite, M.L., Herndorn, R.: The development of the cerebellar cortex of the Syrian Hamster, Mesocricetus auratus. Foliation, cytoarchitectonics, Golgi and EM studies. J. Comp. Neur. 169, 443-480 (1976)

Raaf, J., Kernohan, J.W.: A study of the external granular layer in the cerebellum. The disappearance of the external granular layer and the growth of the molecular and internal granular layer in the cerebellum. Am. J. Anat. 75, 151-172 (1944)

Ramon y Cajal, S.: Histologie du système nerveux de l'homme et des vertébrés. Tome II, Paris: Maloine 1911

Rakic, P.: Kinetics of proliferation and latency between final cell division and onset of differentiation of cerebellar stellate and basket neurons. J. Comp. Neurol. 147, 523-546 (1973)

Robins, E., Lowe, I.P.: Quantitative histochemical studies of the morphogenesis of the cerebellum I. J. Neurochem. 8, 81-95 (1961) 
Romeis, B.: Mikroskopische Technik. München: Oldenbourg 1948

Snell, O.: Die Abhängigkeit des Hirngewichts von dem Körpergewicht und den geistigen Fähigkeiten. Arch. Psych. Nervenkr. 23, 436-446 (1891)

Snider, R.S., Jacobs, J.: Correlation of histogenetic changes in the cerebellum with appearance of electrical activity. Anat. Rec. 103, 559 (1949)

Spann, W., Dustmann, H.O.: Das menschliche Hirngewicht und seine Abhängigkeit von Lebensalter, Körperlänge, Todesursache und Beruf. Dtsch. Z. ges. gerichtl. Med. 44, 733-741 (1965)

Stephan, H.: Methodische Studien über den quantitativen Vergleich architektonischer Struktureinheiten des Gehirns. Z. f. wissensch. Zool. 164, 143-171 (1959)

Uzman, L.L.: The histogenesis of the mouse cerebellum as studied by its tritiated thymidine uptake. J. Comp. Neurol. 114, 137-159 (1960)

Wingert, F.: Biometrische Analyse der Wachstumsfunktionen von Hirnteilen und Körpergewicht der Albinomaus. J. Hirnforsch. 11, 133-197 (1969)

Received May 10, 1977

\section{Appendix}

Table 1. Age of the rats, volumes of the cerebellum and the cerebellar cortex, cerebellar surface

\begin{tabular}{rrrrr}
\hline No. & Days & $\begin{array}{l}\text { Total volume, } \\
\mathrm{mm}^{3}\end{array}$ & $\begin{array}{l}\text { Cortical volume, } \\
\mathrm{mm}^{3}\end{array}$ & $\begin{array}{l}\text { Surface, } \\
\mathrm{mm}^{2}\end{array}$ \\
\hline 1 & 2 & $13.79 \pm 1.20$ & $5.68 \pm 0.31$ & $35.17 \pm 2.46$ \\
2 & 2 & $14.40 \pm 1.04$ & $6.04 \pm 0.24$ & $50.23 \pm 4.68$ \\
3 & 3 & $23.50 \pm 1.93$ & $12.47 \pm 0.87$ & $88.06 \pm 6.31$ \\
4 & 4 & $13.35 \pm 1.27$ & $6.26 \pm 0.43$ & $69.17 \pm 4.17$ \\
5 & 5 & $18.50 \pm 1.69$ & $10.33 \pm 1.06$ & $71.43 \pm 6.29$ \\
6 & 5 & $36.53 \pm 2.47$ & $22.99 \pm 1.47$ & $137.67 \pm 11.47$ \\
7 & 6 & $55.19 \pm 4.89$ & $37.13 \pm 2.65$ & $160.31 \pm 14.21$ \\
8 & 6 & $28.42 \pm 2.76$ & $20.33 \pm 1.39$ & $91.80 \pm 8.67$ \\
9 & 7 & $26.86 \pm 2.41$ & $19.35 \pm 1.74$ & $272.06 \pm 22.33$ \\
10 & 8 & $43.96 \pm 3.96$ & $36.11 \pm 2.27$ & $279.28 \pm 24.90$ \\
11 & 8 & $44.91 \pm 3.73$ & $32.88 \pm 1.96$ & $169.43 \pm 14.06$ \\
12 & 9 & $75.08 \pm 6.11$ & $62.01 \pm 4.19$ & $266.61 \pm 20.13$ \\
13 & 10 & $52.66 \pm 4.22$ & $46.02 \pm 3.56$ & $444.27 \pm 39.60$ \\
14 & 11 & $38.16 \pm 2.67$ & $32.75 \pm 2.64$ & $307.16 \pm 28.83$ \\
15 & 11 & $54.52 \pm 5.91$ & $45.83 \pm 5.06$ & $399.39 \pm 34.06$ \\
16 & 12 & $50.63 \pm 4.60$ & $45.03 \pm 3.55$ & $376.13 \pm 33.79$ \\
17 & 13 & $65.45 \pm 5.11$ & $57.83 \pm 4.72$ & $418.20 \pm 38.56$ \\
18 & 13 & $118.84 \pm 8.56$ & $104.89 \pm 8.56$ & $360.31 \pm 25.61$ \\
19 & 14 & $202.30 \pm 17.19$ & $177.87 \pm 14.15$ & $557.28 \pm 49.30$ \\
20 & 15 & $158.02 \pm 11.45$ & $141.31 \pm 12.64$ & $388.16 \pm 35.48$ \\
21 & 15 & $174.47 \pm 15.06$ & $155.43 \pm 13.69$ & $488.21 \pm 51.09$ \\
22 & 16 & $211.93 \pm 21.23$ & $189.02 \pm 16.41$ & $482.70 \pm 46.36$ \\
23 & 17 & $186.93 \pm 17.21$ & $167.66 \pm 12.21$ & $500.13 \pm 43.16$ \\
24 & 17 & $192.93 \pm 16.57$ & $170.77 \pm 16.31$ & $498.43 \pm 51.67$ \\
25 & 18 & $208.27 \pm 21.03$ & $180.77 \pm 12.06$ & $482.72 \pm 39.11$ \\
26 & 18 & $219.62 \pm 19.63$ & $193.19 \pm 16.07$ & $615.57 \pm 44.53$ \\
27 & 19 & $167.10 \pm 14.71$ & $147.22 \pm 13.43$ & $376.55 \pm 29.60$ \\
28 & 20 & $203.48 \pm 23.26$ & $179.41 \pm 16.17$ & $556.31 \pm 51.13$ \\
29 & 20 & $225.02 \pm 21.65$ & $199.36 \pm 16.34$ & $520.03 \pm 48.65$ \\
30 & 21 & $168.30 \pm 14.22$ & $147.45 \pm 15.69$ & $403.48 \pm 37.01$ \\
31 & 21 & $220.03 \pm 21.60$ & $189.81 \pm 17.56$ & $551.19 \pm 57.44$ \\
32 & 22 & $192.09 \pm 16.44$ & $170.76 \pm 14.21$ & $476.52 \pm 41.71$ \\
33 & 22 & $203.92 \pm 21.56$ & $177.32 \pm 15.04$ & $506.16 \pm 48.69$
\end{tabular}


Table 1-continued

\begin{tabular}{|c|c|c|c|c|}
\hline No. & Days & $\begin{array}{l}\text { Total volume, } \\
\mathrm{mm}^{3}\end{array}$ & $\begin{array}{l}\text { Cortical volume, } \\
\mathrm{mm}^{3}\end{array}$ & $\begin{array}{l}\text { Surface, } \\
\mathrm{mm}^{2}\end{array}$ \\
\hline 34 & 23 & $218.10 \pm 19.34$ & $185.15 \pm 16.48$ & $585.25 \pm 59.55$ \\
\hline 35 & 24 & $239.01 \pm 22.05$ & $209.54 \pm 20.09$ & $535.91 \pm 48.76$ \\
\hline 36 & 25 & $184.01 \pm 17.15$ & $157.20 \pm 12.24$ & $529.12 \pm 53.02$ \\
\hline 37 & 29 & $246.16 \pm 26.34$ & $210.33 \pm 19.75$ & $559.66 \pm 54.17$ \\
\hline 38 & 30 & $234.69 \pm 21.63$ & $199.08 \pm 18.67$ & $553.54 \pm 50.60$ \\
\hline 39 & 35 & $216.40 \pm 19.13$ & $179.75 \pm 15.22$ & $562.32 \pm 41.23$ \\
\hline 40 & 35 & $210.38 \pm 22.20$ & $173.84 \pm 16.47$ & $488.00 \pm 50.72$ \\
\hline 41 & 40 & $224.62 \pm 17.52$ & $189.91 \pm 17.82$ & $520.14 \pm 48.33$ \\
\hline 42 & 40 & $205.19 \pm 19.34$ & $172.75 \pm 15.13$ & $429.63 \pm 37.57$ \\
\hline 43 & 45 & $219.91 \pm 25.67$ & $190.82 \pm 18.46$ & $520.16 \pm 51.09$ \\
\hline 44 & 45 & $211.83 \pm 16.39$ & $176.77 \pm 19.33$ & $411.53 \pm 33.17$ \\
\hline 45 & 47 & $200.70 \pm 17.61$ & $168.57 \pm 11.49$ & $526.13 \pm 41.80$ \\
\hline 46 & 50 & $229.57 \pm 23.49$ & $190.34 \pm 16.31$ & $526.94 \pm 51.49$ \\
\hline 47 & 50 & $215.01 \pm 18.65$ & $176.56 \pm 15.44$ & $460.67 \pm 39.85$ \\
\hline 48 & 55 & $230.57 \pm 21.19$ & $191.06 \pm 20.19$ & $502.06 \pm 46: 39$ \\
\hline 49 & 55 & $223.24 \pm 16.06$ & $185.17 \pm 12.39$ & $510.53 \pm 54.87$ \\
\hline 50 & 57 & $216.84 \pm 20.45$ & $179.23 \pm 16.17$ & $522.19 \pm 39.86$ \\
\hline 51 & 60 & $245.11 \pm 22.79$ & $202.73 \pm 21.65$ & $585.21 \pm 52.49$ \\
\hline 52 & 60 & $198.36 \pm 17.31$ & $162.65 \pm 14.83$ & $528.63 \pm 39.11$ \\
\hline 53 & 63 & $214.50 \pm 22.57$ & $174.05 \pm 15.94$ & $475.27 \pm 32.47$ \\
\hline 54 & 70 & $241.50 \pm 25.74$ & $198.31 \pm 17.39$ & $570.35 \pm 59.33$ \\
\hline 55 & 70 & $223.20 \pm 19.33$ & $182.64 \pm 14.16$ & $535.06 \pm 48.17$ \\
\hline 56 & 79 & $283.54 \pm 30.06$ & $235.80 \pm 25.43$ & $559.51 \pm 43.19$ \\
\hline 57 & 90 & $260.25 \pm 24.77$ & $206.99 \pm 19.45$ & $517.45 \pm 56.73$ \\
\hline 58 & 90 & $225.82 \pm 21.49$ & $178.37 \pm 13.12$ & $467.27 \pm 37.84$ \\
\hline 59 & 99 & $261.66 \pm 29.13$ & $210.13 \pm 21.06$ & $512.36 \pm 54.67$ \\
\hline 60 & 102 & $280.05 \pm 26.91$ & $221.77 \pm 20.84$ & $647.36 \pm 66.04$ \\
\hline 61 & 110 & $307.42 \pm 24.78$ & $251.54 \pm 23.69$ & $612.93 \pm 57.69$ \\
\hline 62 & 112 & $241.52 \pm 20.34$ & $197.33 \pm 18.75$ & $516.44 \pm 41.81$ \\
\hline 63 & 115 & $238.27 \pm 24.67$ & $185.24 \pm 16.11$ & $515.31 \pm 58.34$ \\
\hline 64 & 120 & $264.98 \pm 23.16$ & $203.20 \pm 17.53$ & $501.74 \pm 34.69$ \\
\hline 65 & 120 & $260.90 \pm 24.80$ & $201.39 \pm 20.68$ & $501.56 \pm 61.93$ \\
\hline
\end{tabular}

Table 2. Age of the rats, the volumes of the external and internal granular layer, molecular and medullary layer

\begin{tabular}{rrrrrr}
\hline No. & Days & $\begin{array}{l}\text { Ext. gran. } \\
\text { layer, } \\
\mathrm{mm}^{3}\end{array}$ & $\begin{array}{l}\text { Molecular } \\
\text { layer, } \\
\mathrm{mm}^{3}\end{array}$ & $\begin{array}{l}\text { Internal gran. } \\
\text { layer, } \\
\mathrm{mm}^{3}\end{array}$ & \multicolumn{1}{c}{$\begin{array}{c}\text { Medullary } \\
\text { layer, } \\
\mathrm{mm}^{3}\end{array}$} \\
\hline 1 & 2 & $1.71 \pm 0.14$ & $0.63 \pm 0.04$ & $3.34 \pm 0.21$ & $8.11 \pm 0.64$ \\
2 & 2 & $1.83 \pm 0.13$ & $0.90 \pm 0.06$ & $3.31 \pm 0.17$ & $8.36 \pm 0.72$ \\
3 & 3 & $4.98 \pm 0.39$ & $1.56 \pm 0.13$ & $5.9 \pm 0.36$ & $11.03 \pm 0.81$ \\
4 & 4 & $1.94 \pm 0.16$ & $0.73 \pm 0.04$ & $3.59 \pm 0.21$ & $7.09 \pm 0.94$ \\
5 & 5 & $3.31 \pm 0.36$ & $1.91 \pm 0.14$ & $5.11 \pm 0.48$ & $8.17 \pm 0.66$ \\
6 & 5 & $7.45 \pm 0.57$ & $4.47 \pm 0.57$ & $11.07 \pm 0.91$ & $13.54 \pm 0.97$ \\
7 & 6 & $13.04 \pm 1.04$ & $7.05 \pm 0.36$ & $17.04 \pm 1.45$ & $18.06 \pm 1.45$ \\
8 & 6 & $6.19 \pm 0.55$ & $4.69 \pm 0.39$ & $9.43 \pm 0.66$ & $8.11 \pm 0.77$ \\
9 & 7 & $5.05 \pm 0.43$ & $4.41 \pm 0.51$ & $9.89 \pm 0.82$ & $6.93 \pm 0.51$ \\
10 & 8 & $8.44 \pm 0.61$ & $8.60 \pm 0.60$ & $19.27 \pm 1.73$ & $7.85 \pm 0.64$
\end{tabular}


Table 2-continued

\begin{tabular}{|c|c|c|c|c|c|}
\hline No. & Days & $\begin{array}{l}\text { Ext. gran. } \\
\text { layer, } \\
\mathrm{mm}^{3}\end{array}$ & $\begin{array}{l}\text { Molecular } \\
\text { layer, } \\
\mathrm{mm}^{3}\end{array}$ & $\begin{array}{l}\text { Internal gran. } \\
\text { layer, } \\
\mathrm{mm}^{3}\end{array}$ & $\begin{array}{l}\text { Medullary } \\
\text { layer, } \\
\text { mm }^{3}\end{array}$ \\
\hline 11 & 8 & $9.40 \pm 0.79$ & $6.70 \pm 0.39$ & $16.74 \pm 1.46$ & $12.03 \pm 1.17$ \\
\hline 12 & 9 & $15.03 \pm 0.96$ & $14.33 \pm 1.07$ & $32.65 \pm 2.39$ & $14.08 \pm 1.08$ \\
\hline 13 & 10 & $8.67 \pm 1.20$ & $13.01 \pm 1.29$ & $24.34 \pm 2.57$ & $6.64 \pm 0.32$ \\
\hline 14 & 11 & $6.71 \pm 0.54$ & $8.87 \pm 0.90$ & $17.17 \pm 1.07$ & $5.41 \pm 0.60$ \\
\hline 15 & 11 & $8.96 \pm 0.71$ & $12.04 \pm 1.11$ & $24.83 \pm 2.17$ & $8.69 \pm 0.95$ \\
\hline 16 & 12 & $3.59 \pm 0.33$ & $17.03 \pm 1.43$ & $24.41 \pm 2.60$ & $5.60 \pm 0.44$ \\
\hline 17 & 13 & $8.39 \pm 0.69$ & $19.00 \pm 1.69$ & $30.44 \pm 2.73$ & $7.62 \pm 0.62$ \\
\hline 18 & 13 & $13.07 \pm 1.11$ & $38.09 \pm 3.57$ & $53.73 \pm 6.16$ & $13.95 \pm 0.95$ \\
\hline 19 & 14 & $19.25 \pm 1.69$ & $66.01 \pm 5.10$ & $92.61 \pm 8.57$ & $24.43 \pm 1.96$ \\
\hline 20 & 15 & $19.34 \pm 1.57$ & $48.08 \pm 5.06$ & $73.89 \pm 7.70$ & $16.71 \pm 2.07$ \\
\hline 21 & 15 & $16.31 \pm 1.79$ & $58.04 \pm 4.28$ & $81.08 \pm 9.03$ & $19.04 \pm 1.73$ \\
\hline 22 & 16 & $14.80 \pm 1.33$ & $73.07 \pm 6.31$ & $101.15 \pm 9.87$ & $22.91 \pm 2.46$ \\
\hline 23 & 17 & $16.17 \pm 1.47$ & $65.12 \pm 5.17$ & $86.37 \pm 7.43$ & $19.27 \pm 1.51$ \\
\hline 24 & 17 & $15.23 \pm 1.36$ & $67.48 \pm 6.96$ & $88.06 \pm 8.12$ & $22.16 \pm 1.98$ \\
\hline 25 & 18 & $10.61 \pm 0.98$ & $76.36 \pm 5.23$ & $93.80 \pm 8.57$ & $27.50 \pm 2.14$ \\
\hline 26 & 18 & $10.26 \pm 1.16$ & $84.72 \pm 9.01$ & $98.21 \pm 9.10$ & $26.43 \pm 2.57$ \\
\hline 27 & 19 & $12.04 \pm 1.04$ & $60.56 \pm 5.11$ & $74.69 \pm 6.43$ & $19.81 \pm 1.68$ \\
\hline 28 & 20 & $6.53 \pm 0.41$ & $84.31 \pm 7.65$ & $88.57 \pm 8.06$ & $24.07 \pm 2.16$ \\
\hline 29 & 20 & $6.81 \pm 0.69$ & $92.80 \pm 8.43$ & $99.75 \pm 11.14$ & $25.66 \pm 2.80$ \\
\hline 30 & 21 & $7.01 \pm 0.61$ & $68.62 \pm 6.10$ & $71.82 \pm 6.08$ & $20.85 \pm 1.76$ \\
\hline 31 & 21 & $5.40 \pm 0.39$ & $84.53 \pm 7.64$ & $99.88 \pm 9.34$ & $30.22 \pm 2.86$ \\
\hline 32 & 22 & $1.71 \pm 0.14$ & $88.77 \pm 9.26$ & $80.28 \pm 7.66$ & $21.33 \pm 1.63$ \\
\hline 33 & 22 & $1.92 \pm 0.19$ & $86.84 \pm 8.04$ & $88.56 \pm 0.03$ & $26.60 \pm 2.40$ \\
\hline 34 & 23 & $2.18 \pm 0.26$ & $93.54 \pm 9.09$ & $89.43 \pm 8.50$ & $32.95 \pm 2.96$ \\
\hline 35 & 24 & $0.34 \pm 0.03$ & $103.60 \pm 11.20$ & $105.60 \pm 8.98$ & $29.47 \pm 2.61$ \\
\hline 36 & 25 & & $80.39 \pm 8.16$ & $76.81 \pm 6.65$ & $26.81 \pm 2.44$ \\
\hline 37 & 29 & & $108.11 \pm 9.47$ & $102.23 \pm 11.27$ & $36.42 \pm 3.15$ \\
\hline 38 & 30 & & $105.25 \pm 8.56$ & $93.83 \pm 8.44$ & $35.61 \pm 3.52$ \\
\hline 39 & 35 & & $94.06 \pm 8.13$ & $85.71 \pm 6.59$ & $36.63 \pm 3.13$ \\
\hline 40 & 35 & & $93.19 \pm 9.80$ & $80.65 \pm 8.75$ & $36.54 \pm 3.75$ \\
\hline 41 & 40 & & $101.48 \pm 11.41$ & $88.43 \pm 8.21$ & $34.71 \pm 4.88$ \\
\hline 42 & 40 & & $98.56 \pm 7.39$ & $74.19 \pm 5.54$ & $32.44 \pm 2.76$ \\
\hline 43 & 45 & & $106.47 \pm 9.04$ & $84.30 \pm 6.73$ & $29.09 \pm 2.43$ \\
\hline 44 & 45 & & $98.51 \pm 8.34$ & $78.26 \pm 8.30$ & $35.11 \pm 3.06$ \\
\hline 45 & 47 & & $90.34 \pm 8.74$ & $78.23 \pm 6.43$ & $32.16 \pm 2.24$ \\
\hline 46 & 50 & & $107.17 \pm 9.27$ & $83.17 \pm 7.21$ & $39.23 \pm 3.16$ \\
\hline 47 & 50 & & $104.22 \pm 11.13$ & $72.43 \pm 6.16$ & $38.45 \pm 2.26$ \\
\hline 48 & 55 & & $100.56 \pm 9.06$ & $90.50 \pm 8.45$ & $39.51 \pm 4.18$ \\
\hline 49 & 55 & & $105.39 \pm 10.15$ & $79.78 \pm 7.11$ & $38.07 \pm 3.02$ \\
\hline 50 & 57 & & $93.27 \pm 8.90$ & $86.01 \pm 8.04$ & $38.58 \pm 3.47$ \\
\hline 51 & 60 & & $112.56 \pm 10.43$ & $90.17 \pm 8.76$ & $42.39 \pm 5.19$ \\
\hline 52 & 60 & & $90.39 \pm 7.56$ & $72.26 \pm 6.43$ & $35.71 \pm 3.21$ \\
\hline 53 & 63 & & $96.71 \pm 8.64$ & $77.34 \pm 7.19$ & $40.45 \pm 4.07$ \\
\hline 54 & 70 & & $110.60 \pm 10.47$ & $87.71 \pm 8.20$ & $43.19 \pm 3.86$ \\
\hline 55 & 70 & & $105.04 \pm 9.39$ & $77.60 \pm 6.86$ & $40.56 \pm 3.57$ \\
\hline 56 & 79 & & $131.37 \pm 12.09$ & $104.43 \pm 11.43$ & $47.71 \pm 4.25$ \\
\hline 57 & 90 & & $113.54 \pm 10.41$ & $93.45 \pm 8.26$ & $53.26 \pm 5.06$ \\
\hline 58 & 90 & & $100.79 \pm 8.75$ & $77.57 \pm 7.51$ & $47.51 \pm 4.22$ \\
\hline 59 & 99 & & $116.52 \pm 19.42$ & $93.61 \pm 8.56$ & $51.43 \pm 4.64$ \\
\hline 60 & 102 & & $124.22 \pm 11.39$ & $97.55 \pm 9.43$ & $58.28 \pm 5.37$ \\
\hline 61 & 110 & & $141.45 \pm 12.63$ & $110.09 \pm 10.14$ & $56.16 \pm 5.25$ \\
\hline 62 & 112 & & $108.85 \pm 9.77$ & $88.48 \pm 7.22$ & $44.19 \pm 3.80$ \\
\hline 63 & 115 & & $100.09 \pm 8.47$ & $85.15 \pm 8.39$ & $53.03 \pm 4.75$ \\
\hline 64 & 120 & & $115.71 \pm 9.78$ & $87.49 \pm 9.06$ & $61.78 \pm 5.48$ \\
\hline 65 & 120 & & $113.66 \pm 8.91$ & $87.73 \pm 8.49$ & $59.51 \pm 5.25$ \\
\hline
\end{tabular}


Table 3 Age of the rats, thickness of the external and internal granular layer and the molecular layer

\begin{tabular}{|c|c|c|c|c|}
\hline No. & Days & $\begin{array}{l}\text { Ext. gran. layer, } \\
\mu \mathrm{m}\end{array}$ & $\begin{array}{l}\text { Molecular layer, } \\
\mu \mathrm{m}\end{array}$ & $\begin{array}{l}\text { Int. gran. layer, } \\
\mu \mathrm{m}\end{array}$ \\
\hline 1 & 2 & $48.62 \pm 3.79$ & $18.14 \pm 1.06$ & $94.96 \pm 8.17$ \\
\hline 2 & 2 & $36.43 \pm 2.46$ & $17.92 \pm 1.29$ & $65.90 \pm 4.32$ \\
\hline 3 & 3 & $56.55 \pm 4.67$ & $17.72 \pm 1.34$ & $67.34 \pm 5.48$ \\
\hline 4 & 4 & $28.05 \pm 2.16$ & $10.55 \pm 0.87$ & $51.90 \pm 5.20$ \\
\hline 5 & 5 & $46.34 \pm 4.25$ & $26.75 \pm 1.73$ & $71.54 \pm 6.42$ \\
\hline 6 & 5 & $54.11 \pm 3.87$ & $32.47 \pm 2.46$ & $80.41 \pm 6.06$ \\
\hline 7 & 6 & $81.34 \pm 9.46$ & $43.98 \pm 3.98$ & $106.29 \pm 9.35$ \\
\hline 8 & 6 & $67.43 \pm 6.15$ & $51.09 \pm 4.63$ & $102.72 \pm 11.46$ \\
\hline 9 & 7 & $18.56 \pm 1.40$ & $16.25 \pm 1.08$ & $36.25 \pm 2.87$ \\
\hline 10 & 8 & $30.22 \pm 2.55$ & $30.79 \pm 2.94$ & $69.21 \pm 6.33$ \\
\hline 11 & 8 & $55.48 \pm 4.57$ & $39.78 \pm 3.16$ & $98.80 \pm 8.54$ \\
\hline 12 & 9 & $56.37 \pm 5.24$ & $53.75 \pm 5.31$ & $122.46 \pm 10.61$ \\
\hline 13 & 10 & $19.52 \pm 1.63$ & $29.28 \pm 2.70$ & $54.70 \pm 4.27$ \\
\hline 14 & 11 & $21.85 \pm 1.80$ & $28.88 \pm 2.94$ & $55.90 \pm 4.93$ \\
\hline 15 & 11 & $22.43 \pm 2.35$ & $30.15 \pm 2.63$ & $62.17 \pm 3.86$ \\
\hline 16 & 12 & $9.54 \pm 0.74$ & $45.28 \pm 4.17$ & $64.90 \pm 6.01$ \\
\hline 17 & 13 & $20.06 \pm 1.83$ & $45.43 \pm 2.40$ & $72.79 \pm 6.76$ \\
\hline 18 & 13 & $36.27 \pm 3.54$ & $105.71 \pm 10.21$ & $149.12 \pm 13.29$ \\
\hline 19 & 14 & $34.54 \pm 3.26$ & $118.45 \pm 11.39$ & $166.18 \pm 15.41$ \\
\hline 20 & 15 & $49.82 \pm 4.22$ & $123.87 \pm 11.50$ & $190.36 \pm 19.25$ \\
\hline 21 & 15 & $33.41 \pm 3.68$ & $118.88 \pm 10.07$ & $166.08 \pm 14.57$ \\
\hline 22 & 16 & $30.66 \pm 2.84$ & $151.38 \pm 12.38$ & $209.55 \pm 18.44$ \\
\hline 23 & 17 & $32.33 \pm 2.66$ & $130.21 \pm 11.44$ & $172.70 \pm 16.12$ \\
\hline 24 & 17 & $30.56 \pm 2.79$ & $135.39 \pm 12.21$ & $176.67 \pm 14.35$ \\
\hline 25 & 18 & $21.98 \pm 1.85$ & $158.19 \pm 12.83$ & $194.32 \pm 18.47$ \\
\hline 26 & 18 & $16.67 \pm 1.49$ & $137.63 \pm 14.61$ & $159.54 \pm 12.31$ \\
\hline 27 & 19 & $31.97 \pm 2.97$ & $160.83 \pm 15.40$ & $198.35 \pm 18.15$ \\
\hline 28 & 20 & $11.74 \pm 1.07$ & $151.55 \pm 18.27$ & $159.21 \pm 21.19$ \\
\hline 29 & 20 & $13.10 \pm 1.42$ & $178.45 \pm 16.14$ & $191.82 \pm 17.43$ \\
\hline 30 & 21 & $17.31 \pm 1.89$ & $170.07 \pm 18.22$ & $178.00 \pm 15.16$ \\
\hline 31 & 21 & $9.80 \pm 0.87$ & $153.36 \pm 13.56$ & $181.21 \pm 19.85$ \\
\hline 32 & 22 & $3.59 \pm 0.36$ & $186.29 \pm 16.29$ & $168.47 \pm 16.73$ \\
\hline 33 & 22 & $3.79 \pm 0.41$ & $171.57 \pm 16.15$ & $174.96 \pm 18.16$ \\
\hline 34 & 23 & $3.72 \pm 0.28$ & $159.83 \pm 19.83$ & $152.81 \pm 19.42$ \\
\hline 35 & 24 & $1.08 \pm 0.12$ & $193.32 \pm 18.49$ & $187.72 \pm 18.77$ \\
\hline 36 & 25 & $0.063 \pm 0.0005$ & $151.93 \pm 12.08$ & $145.16 \pm 15.50$ \\
\hline 37 & 29 & & $193.17 \pm 20.60$ & $182.66 \pm 17.19$ \\
\hline 38 & 30 & & $190.14 \pm 18.57$ & $169.51 \pm 17.83$ \\
\hline 39 & 35 & & $167.31 \pm 14.31$ & $152.42 \pm 14.29$ \\
\hline 40 & 35 & . & $190.96 \pm 21.12$ & $165.27 \pm 15.07$ \\
\hline 41 & 40 & & $195.10 \pm 18.76$ & $170.01 \pm 14.90$ \\
\hline 42 & 40 & & $229.41 \pm 21.60$ & $173.38 \pm 16.78$ \\
\hline 43 & 45 & & $204.69 \pm 19.54$ & $162.07 \pm 17.11$ \\
\hline 44 & 45 & & $239.38 \pm 22.41$ & $190.17 \pm 18.64$ \\
\hline 45 & 47 & & $171.71 \pm 16.42$ & $149.69 \pm 13.87$ \\
\hline 46 & 50 & & $203.38 \pm 21.36$ & $157.84 \pm 16.07$ \\
\hline 47 & 50 & & $226.24 \pm 19.84$ & $157.23 \pm 14.26$ \\
\hline 48 & 55 & & $200.29 \pm 21.22$ & $180.26 \pm 16.19$ \\
\hline 49 & 55 & & $206.43 \pm 18.09$ & $156.27 \pm 16.15$ \\
\hline 50 & 57 & & $178.61 \pm 16.53$ & $164.71 \pm 14.56$ \\
\hline 51 & 60 & & $192.43 \pm 18.41$ & $154.09 \pm 14.23$ \\
\hline 52 & 60 & & $170.99 \pm 18.79$ & $136.69 \pm 12.20$ \\
\hline 53 & 63 & & $203.48 \pm 21.08$ & $162.73 \pm 15.35$ \\
\hline 54 & 70 & & $193.92 \pm 18.21$ & $153.78 \pm 16.87$ \\
\hline 55 & 70 & & $189.93 \pm 16.95$ & $140.31 \pm 13.46$ \\
\hline 56 & 79 & & $234.79 \pm 24.36$ & $186.48 \pm 16.32$ \\
\hline
\end{tabular}


Table 3-continued

\begin{tabular}{|c|c|c|c|c|}
\hline No. & Days & $\begin{array}{l}\text { Ext. gran. layer, } \\
\mu \mathrm{m}\end{array}$ & $\begin{array}{l}\text { Molecular layer, } \\
\mu \mathrm{m}\end{array}$ & $\begin{array}{l}\text { Int. gran. layer, } \\
\mu \mathrm{m}\end{array}$ \\
\hline $\begin{array}{l}57 \\
58 \\
59 \\
60 \\
61 \\
62 \\
63 \\
64 \\
65 \\
\end{array}$ & $\begin{array}{r}90 \\
90 \\
99 \\
102 \\
110 \\
112 \\
115 \\
120 \\
120\end{array}$ & & $\begin{array}{l}219.42 \pm 21.73 \\
215.70 \pm 18.50 \\
227.42 \pm 21.39 \\
191.96 \pm 17.40 \\
230.78 \pm 24.68 \\
210.77 \pm 19.18 \\
194.99 \pm 20.25 \\
230.67 \pm 22.01 \\
226.61 \pm 23.28\end{array}$ & $\begin{array}{l}180.34 \pm 19.36 \\
166.02 \pm 18.69 \\
182.70 \pm 17.41 \\
150.75 \pm 12.10 \\
179.61 \pm 16.17 \\
171.33 \pm 16.41 \\
165.85 \pm 17.53 \\
174.37 \pm 16.68 \\
118.65 \pm 18.73\end{array}$ \\
\hline
\end{tabular}

